\title{
Is total serum protein a good indicator for welfare in reared sea bass (Dicentrarchus labrax)?
}

\author{
Jean-Luc Coeurdacier ${ }^{1, a}$, Gilbert Dutto ${ }^{2}$, Eric Gasset ${ }^{2}$ and Jean-Paul Blancheton ${ }^{2}$ \\ 1 IFREMER, HMT, Centre de recherche halieutique méditerranéenne et tropicale, avenue Jean Monnet, BP 171, 34203 Sète Cedex, France \\ 2 IFREMER, LRPM, Station de recherche en Pisciculture de Méditerranée, route de Maguelone, 34250 Palavas les Flots, France
}

Received 12 May 2010; Accepted 4 May 2011

\begin{abstract}
Reared sea bass were submitted to six stressful situations: hyperoxia with or without hypercapnia, increased stocking density in an open flow or recirculating system, transfer to another tank and nodavirus injection. The potentially negative impact of these factors on the lives of sea bass was investigated by measuring 9 water parameters and 19 fish parameters including total serum protein (TSP). TSP has already been used to evaluate stress. The present study investigates data of previous and new experiments, concentrating on the potential use of TSP as a routine indicator to assess welfare in sea bass reared on fish farms. In the current experiment, oxygen and carbon dioxide were seen to affect levels of TSP, but alterations were too erratic to enable proper comparison, probably because they are normal components of the fish environment and become toxic only by dose increase. TSP decreased when stocking density increased. After transfer to another tank, TSP decreased to $14 \%$ for three weeks and then increased during the fourth week through compensative overproduction, before returning to normal levels after 2 months. The results confirmed that transfer is an important stress factor for fish, with cumulative effects for successive transfers. TSP alteration of nodavirus-injected fish depends on the type of symptoms, which can be divided into 3 groups: (i) dying fish, in which TSP increased sharply due to over-production of protein involved in non-specific defences and inflammation, then decreased dramatically before death; (ii) whirling fish, a group that included both fish that later died, in which TSP decreased, and fish that subsequently survived, in which TSP increased due to development of specific immunity; and (iii) asymptomatic fish, in which TPS was similar to control levels and which were probably insensitive to nodavirus and/or had developed defences. In this paper, different mechanisms of TSP alteration are proposed and the interest of TSP as a field parameter is discussed. TSP is a non-destructive parameter that is robust, easy to measure everywhere and cheap, representing a suitable way of monitoring the overall welfare of fish by its regular increase. It can be used only as a "warning" of poor rearing conditions, however, and further investigations would be needed to identify the specific stress or health disorder.
\end{abstract}

Key words: Fish stress / Fish welfare / Protein / Serum / Fish transfer / Nodavirus / Sea bass

\section{Introduction}

Despite continuous improvements of diagnoses, sanitary controls, proactive treatments and methods such as vaccinations, the health and welfare of farmed fish remains a major issue for the European aquaculture industry. Both environmental conditions and husbandry practices can impact fish health and welfare. The welfare and health in sustainable aquaculture (WEALTH) project aimed to present a holistic view of how the health and welfare of farmed fish can be maximized. Its final goal was to develop and validate an operational husbandry management protocol for the aquaculture industry.

Six potential stressful situations were studied: hyperoxia, hyperoxia and hypercapnia, crowding in open flow (OFS) and in recirculating systems (RS), transfer to another tank,

\footnotetext{
${ }^{a}$ Corresponding author: jlcoeurd@ifremer.fr
}

and nodavirus injection. To discriminate between these situations, many parameters were measured with regards to sea water quality (temperature, salinity, oxygen, $\mathrm{pH}$, ammonia, urea, nitrite, nitrate and phosphate), fish condition (swimming behaviour, feed intake, growth rate, feed, conversion ratio, wounds or fin damage) and blood parameters (cortisol, sodium, potassium, chloride, $\mathrm{pH}$, urea, glucose, hematocrit, haemoglobin, $\mathrm{pCO}_{2}$ and $\mathrm{HCO}_{3}$, and total serum protein (TSP).

Data concerning hyperoxia, hypercapnia and crowding have already been examined in order to investigate the impact of each stressful situation on health and welfare (Taranger 2008; Sammouth et al. 2008; Roque d'Orbcastel et al. 2010). In this previous work, the fish reared with the highest oxygen level treatment $\left(250 \mathrm{HP}\right.$ : tanks at $230-250 \% \mathrm{O}_{2}$ saturation $16.4-17.8 \mathrm{mg} \mathrm{L}^{-1}$ with a total gas pressure at $230 \mathrm{~mm} \mathrm{Hg}$ ) were the most affected, with mortalities of 10 to $15 \%$ fish/tank, 
a clearer body colour than control fish and irregular greyishwhite patches at the bases of the dorsal, caudal and pectoral fins. The dead fish showed tiny gas bubbles in their eyes and in the skin of their fins when removed from the water. Feed intake and its conversion were modified. The daily amount of ingested food (DAIF) showed large variations, the specific growth rate (SGR) was significantly affected, and the feed conversion rate (FCR) was significantly higher $(+16 \%)$.

The fish submitted to the "High" treatment, with hyperoxia and hypercapnia $\left(250 \% \mathrm{O}_{2}\right.$ saturation, $\left.\mathrm{CO}_{2}: 50 \mathrm{mg} \mathrm{L}^{-1}\right)$, showed a clear difference in swimming activity from the others. They swam in slow motion and remained in a group in the middle of the tank. When fed, the fish were indifferent towards the food and had a low feeding activity. Within a period of 30 days, however, the swimming and feeding behaviour of the fish became progressively similar to that of the control fish. The DAIF per tank showed large variations and average feed intake was $84 \%$ of the control. The overall SGR was deeply and significantly affected and represented $84.5 \%$ of the growth. In blood, $\mathrm{pCO}_{2}$ and $\mathrm{HCO}_{3}$ increased dramatically and hematocrit and haemoglobin content decreased. The apparent oxygen uptake was significantly higher $(+32 \%)$ compared with the control fish. The behaviour of the fish submitted to the "medium" treatment $\left(150 \% \mathrm{O}_{2}\right.$ saturation, $\left.\mathrm{CO}_{2}: 25 \mathrm{mg} \mathrm{L}^{-1}\right)$ was intermediate between that of the high treatment and the control $\left(100 \% \mathrm{O}_{2}\right.$ saturation, $\left.\mathrm{CO}_{2} 0 \mathrm{mg} \mathrm{L}^{-1}\right)$. Rearing fish at high density ( $100 \mathrm{~kg} \mathrm{~m}^{-3}$ of seawater) induced a difference in swimming behaviour compared with the control $\left(10 \mathrm{~kg} \mathrm{~m}^{-3}\right)$. This observation was made in both the flow-through and recirculating systems. A negative effect was seen on feed intake $(-10 \%)$, growth and alterations observed in blood parameters $\left(\mathrm{pCO}_{2}\right.$ and $\mathrm{HCO}_{3}$ were higher) in the $100 \mathrm{~kg} \mathrm{~m}^{-3}$ group in the flow-through system. The study suggested that only high stocking density $\left(100 \mathrm{~kg} \mathrm{~m}^{-3}\right)$ had a negative effect. Complete information from this study is published elsewhere (Taranger 2008; Sammouth et al. 2008; Roque d'Orbcastel et al. 2010).

Alterations in total plasma or serum protein concentration relative to a reference interval have been used as a broad clinical indicator of health, stress, and well being of terrestrial and aquatic organisms (Riche 2007). TSP was used as a bioindicator of stress by salinity alteration in the plasma of hybrid striped bass (Morone chrysops $\times$ M. saxatilis; Riche 2007); for pollution stress, in the serum of catfish (Clarias lazera) (Adham et al. 1999), carp (Cyprinus carpio) (Gopal et al. 1997) and Nile tilapia (Oreochromis nicoticus) (ElGohary et al. 2005); and for starvation stress in carp (Friedrich and Stepanowska 2001). TSP was also used to determine crowding stress in trout (Oncorhynchus mykiss) (Sutton et al. 2000); ammonia stress in sea bass (Dicentrarchus labrax) (Coeurdacier and Dutto 1999); temperature stress in cod (Gadus morhua) (Magnadottir et al. 1999); transport stress in dab (Limanda limanda) (Hutchinson and Manning 1996), matrinxã (Brycon amazonicu) (Carneiro and Urbinati 2002; Urbinati and Carneiro 2006) and trout (Oncorhynchus mykiss) (Jeney et al. 1997); and stress following infection in carp (Cyprinus carpio) (Steinhagen et al. 1997) and brown trout (Salmo trutta) (Ingram and Alexander 1977).

Previous publications on our experiments (Sammouth et al. 2008; Taranger, 2008; Roque d'Orbcastel et al. 2010) report the negative impact of these four stress conditions on the fish. As described in the other papers cited above, TSP is widely used to monitor stress situations in fish. The present study investigates TSP in response to previously studied conditions and new situations (transfer and nodavirus injection) in order to determine its potential use as a routine indicator for assessing welfare and possibly stress in sea bass reared on fish farms.

\section{Materials and methods}

We first provide a summary of the materiel and methods used in the previous experiments (hyperoxia, hypercapnia and stocking density). Their full details and subsequent results are described in Sammouth et al. (2008), Taranger (2008) and Roque d'Orbcastel et al. (2010). For the transfer and nodavirus injection treatments, the general conditions of rearing and monitoring are the same.

\subsection{Rearing conditions}

All experiments were carried out at the IFREMER Research Station at Palavas-les-Flots (France). Sea bass sibs were supplied on two dates (one sibs per year) by the Méditerranée Pisciculture Farm (Salses-le-Château, France). Except when specifically mentioned, rearing conditions were identical for all experiments. The two sibs, after an acclimatization period ( 2 months), were stocked in $1 \mathrm{~m}^{3}$ tanks. Except for nodavirus injection, the original fish weights were 75-150 g, depending on the experiment and duration (3-4 months, i.e., enough time for the fish to double their original weight). The fish were fed to satiation, and all hexogen stress was avoided (light, noise, hour modification for monitoring etc.). The water temperature was $21^{\circ} \mathrm{C}$, and the photoperiod was $16 \mathrm{~h}$ light and $8 \mathrm{~h}$ dark. The water parameters were maintained constant, above the rearing level limits, throughout the experiment. Water samples were collected regularly to monitor temperature, salinity, oxygen, $\mathrm{pH}$, ammonia, urea, nitrite, nitrate, phosphate and, when necessary, specific parameters such as carbon dioxide, humic substances, and total gas pressure.

\subsection{Sampling and total serum protein}

Blood samples $(0.5 \mathrm{ml})$ were collected from 30 or more ( $n=30-33$ ) fish midway through and at the end of the experiment, unless otherwise specified. The fish were starved for $24 \mathrm{~h}$ before sampling. Blood was taken from the caudal vein on 10 fish anaesthetized for $3 \mathrm{~min}$ at $4{ }^{\circ} \mathrm{C}$ in seawater and sampled within 5 min of fish capture to avoid TSP modification by handling stress. Serum was separated by centrifugation (15000 rpm, $5 \mathrm{~min}, 4^{\circ} \mathrm{C}$ ) and stored at $-20^{\circ} \mathrm{C}$ until analysis. A Max Mat Hycel autoanalyzer determined TSP, based on the principle of the biuret reaction. Bovine serum albumin (BSA) was used as a standard and data were expressed in $\mathrm{mg} \mathrm{ml}^{-1}$.

\subsection{Hyperoxia}

Fish (mean body weight $80 \pm 3 \mathrm{~g}$ ) were distributed among 15 tanks of $1 \mathrm{~m}^{3}$ each at a stocking density of $15-20 \mathrm{~kg} \mathrm{~m}^{-3}$ 
(in triplicate for each treatment). The stocking density was maintained by removing excess biomass every 3 weeks. The experiment lasted 12 weeks.

- Control: tanks at $90-100 \% \mathrm{O}_{2}$ saturation (close to equilibrium).

- 150 LP: tanks at $140-150 \% \quad \mathrm{O}_{2}$ saturation (9.9 to $10.7 \mathrm{mg} \mathrm{L}^{-1}$ ) with a total gas pressure of $15 \mathrm{~mm} \mathrm{Hg}$ (low level).

- 150 HP: tanks at $140-150 \% \quad \mathrm{O}_{2}$ saturation (9.9 to $10.7 \mathrm{mg} \mathrm{L}^{-1}$ ) with a total gas pressure $160 \mathrm{~mm} \mathrm{Hg}$ (high level).

- $250 \mathrm{HP}$ : tanks at $230-250 \% \mathrm{O}_{2}$ saturation (16.4 to $17.8 \mathrm{mg} \mathrm{L}^{-1}$ ) with a total gas pressure of $230 \mathrm{~mm} \mathrm{Hg}$ (very high level).

\subsection{Hyperoxia combined with hypercapnia}

Fish (mean individual body weight $78 \pm 3$ g) were distributed among 15 tanks of $1 \mathrm{~m}^{3}$ each, with a stocking density of 15 to $20 \mathrm{~kg} \mathrm{~m}^{-3}$ (in triplicate for each treatment). The stocking density was maintained by removing excess biomass every 3 weeks. The experiment lasted 9 weeks.

- Control: $100 \% \mathrm{O}_{2}$ saturation, $\mathrm{CO}_{2}: 0 \mathrm{mg} \mathrm{L}^{-1}$.

- Intermediate: $150 \% \mathrm{O}_{2}$ saturation, $\mathrm{CO}_{2}: 25 \mathrm{mg} \mathrm{L}^{-1}$.

- High: $250 \% \mathrm{O}_{2}$ saturation, $\mathrm{CO}_{2}: 50 \mathrm{mg} \mathrm{L}^{-1}$.

\subsection{Stocking density}

Fish (mean body weight $75 \pm 2$ g) were distributed among 15 tanks of $1 \mathrm{~m}^{3}$ each, at densities of 10, 40, 70, and $100 \mathrm{~kg} \mathrm{~m}^{-3}$ (in triplicate for each treatment) in an open flow system and at densities of 10,70 , and $100 \mathrm{~kg} \mathrm{~m}^{-3}$ in recirculating system. The stocking density was maintained by removing excess biomass every 3 weeks. The experiment lasted 9 weeks.

\subsection{Transfer to other tank}

Fish (mean body weight $75 \pm 2 \mathrm{~g}$ ) were distributed among 15 tanks of $1 \mathrm{~m}^{3}$ each at densities of 15 to $20 \mathrm{~kg} \mathrm{~m}^{-3}$ (in triplicate). The stocking density was maintained by removing excess biomass every 3 weeks. To avoid problems during transfer, fish was fasted for $24 \mathrm{~h}$ before transfer. Experiments on single transfer lasted 9 weeks and 18 weeks those on multiple transfers. Results concerning each experiment are expressed in $\mathrm{mg} \mathrm{ml}^{-1} \pm \mathrm{SE}$ (standard error). For the general evolution of TSP, the result was based on around 1300 samples performed on 10 different groups from 2 sibs (experiments were repeated twice). In this case, results are expressed in Protein Percentage Alteration (PPA definition in Sect. 2.7.). PPA is used to balance differences in sizes and sibs of fish. Percentage mean was used for PPA ( $\mathrm{n}$ is equivalent $=30-32$ fish), but this does not allow a confidence interval to be obtained.

\subsection{Nodavirus injection}

Fish (240 individuals, mean body weight $230 \pm 5 \mathrm{~g}$ ) were individually tagged, 105 were intramuscularly inoculated with a nodavirus suspension of $9 \times 10^{5} \mathrm{PFU} /$ fish, (method described by Coeurdacier et al. 2003). The control group (35 fish) was injected with sterile $\mathrm{SSN}_{1}$ cell culture solution. Two parallel and independent recirculating systems of three tanks $\left(1 \mathrm{~m}^{3}\right)$ were used; one for inoculated fish and the other for controls. Fish were fed to satiety and the water temperature was $25^{\circ} \mathrm{C}$. Total morbidity and fish showing abnormal swimming behaviour were recorded daily for 3 weeks. Fish were sampled before injection and when they were whirling or dying. Asymptomatic and control $\left(\mathrm{SSN}_{1}\right.$-injected) fish were sampled at the end of experimentation (3 weeks).

Data are individual results and expressed in PPA (\%).

\subsection{Data treatment}

The means shown on the graphs are expressed in $\mathrm{mg} \mathrm{ml} \mathrm{m}^{-1} \pm \mathrm{SE}$ (standard error). Statistical analysis was performed using SigmaStat 2.0. To compare more than two groups, one way ANOVA of variance or on rank (Kruskal-Wallis) were used and pair-wise comparison procedures ( $t$-test, Tukey test and Dunn's method) were used for two groups. Results were considered statistically different at $p \leqslant 0.05$.

Age of fish and the sibs can influence TSP (Coeurdacier et al. 1997). To allow comparison, data were balanced using percentage of variation instead of $\mathrm{mg} \mathrm{ml}^{-1}$. Protein percentage alteration (PPA) was used:

PPA $=($ TSP terminal - TSP original $) /$ TSP original.

PPA enabled data to be balanced from transfer to another tank, which concerned 10 groups with different weights from the two sibs. PPA optimizes individual variation obtained with individually tagged fish (nodavirus injection).

Daily augmentation of PPA is about $0.2 \%$ for sea bass up to $250 \mathrm{~g}$ (Coeurdacier and Dutto 1999), but no information is available for larger fish. A difference between adults and observed in trout (Sutton et al. 2000). For broodstocks, this variation changes with season in sea bass (Coeurdacier et al. 1997) and in dab (Hutchinson and Manning 1996). We used this $0.2 \%$ by day to calculate a "standard" increase.

\section{Results}

\subsection{Erratic total serum protein alteration by hyperoxia or/and hypercapnia}

At the end of the hyperoxia experiment, TPS in the fish in treatment 150 LP were significantly different from the control ( $t$-test, $p<0.05$ ), and TSP had decreased, although not significantly, in other treatments. The treatment by $\mathrm{O}_{2}$ and $\mathrm{CO}_{2}$, affected TSP, but large individual variations made the data too erratic to enable proper comparison (results not shown).

\subsection{TSP decrease with stocking density increase}

Stocking density induces differences $(p<0.05)$ in TSP between highest and lowest densities midway through the experiment $\left(100 \mathrm{~kg} \mathrm{~m}^{-3}, 70 \mathrm{~kg} \mathrm{~m}^{-3}\right.$ at day 21 for open flow (OFS) and $100 \mathrm{~kg} \mathrm{~m}^{-3}$ at day 43 for RS), with a median position 


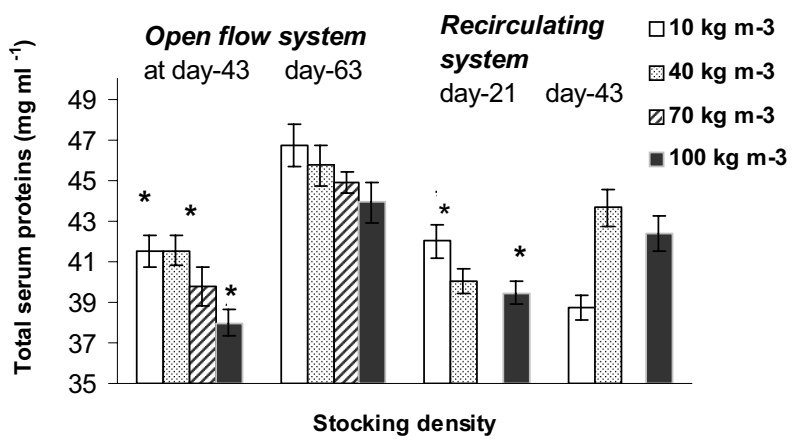

Fig. 1. Total serum protein (TSP, $\mathrm{mg} \mathrm{ml}^{-1} \pm \mathrm{SE}$ ) variation according to stocking density in two independent experiments: in an open flow system (left), and in a recirculating system (right) on days 21 and 43, at different stocking densities (left to right) $10,40,70,100 \mathrm{~kg} \mathrm{~m}^{-3}$ $(n=30 ; * p<0.05)$.

for $40 \mathrm{~kg} \mathrm{~m}^{-3}$ (Fig. 1). At the end of experiment, the general tendency was maintained for OFS but with no significant difference (day 63).

\subsection{TSP decrease after transfer to another tank}

Around 1300 samples were analysed and the data was treated using TSP alteration or PPA. In the present paper, we chose to present three representative cases (expressed in $\mathrm{mg} \mathrm{ml}^{-1} \pm \mathrm{SE}$ ) and the overall evolution (expressed in PPA) of all results.

After transfer to another tank, fish had different behaviour patterns compared with the controls that had not been transferred. They took time to recover normal feeding and their growth slowed down, but weights attained the same levels as those of non-transferred fish after one month.

\section{TSP decrease in transferred groups}

The same batch divided into four groups presented an important and significant $(p<0.05)$ decrease in TSP after transfer. Other parameters (tank and density) slightly modified the level of alteration. This example (Fig. 2), with 4 consecutive results from four groups of the same sibs is a good illustration of TSP alteration after transfer. TSP decreases after each transfer (day 21 and day 63) in all groups. It increases when no transfer occurs (between day 21 and day 42).

\section{TSP decrease in transferred fish and increase in non-transferred fish}

The TSP (Fig. 3) of non-transferred fish continued to increase but the TSP of transferred fish first stopped (day 7) and then decreased (day 27), increasing the deficit in serum protein compared with non-transferred fish.

\section{Overall change after a single transfer}

Overall evolution during the 10 weeks after a single transfer is shown in Figure 4. PPA decreased drastically during the second and third weeks after transfer, with the lowest value at

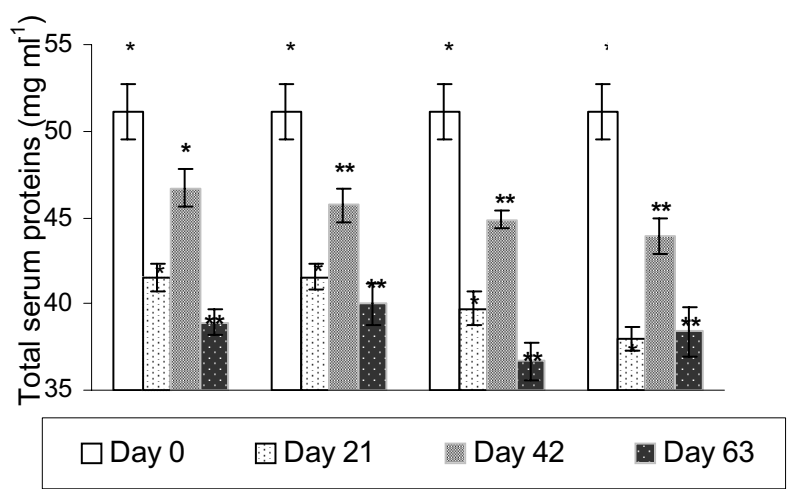

Fig. 2. Total serum protein (TSP, $\mathrm{mg} \mathrm{ml}^{-1} \pm \mathrm{SE}$ ) decreases in all fish groups after fish transfer. Four groups issued from the same batch were transferred at days 0 and 42 . Fish were sampled every 3 weeks: at days $0,21,42$ and 63 . TSP of all successive samples was different $(n=30 ; p<0.05)$.

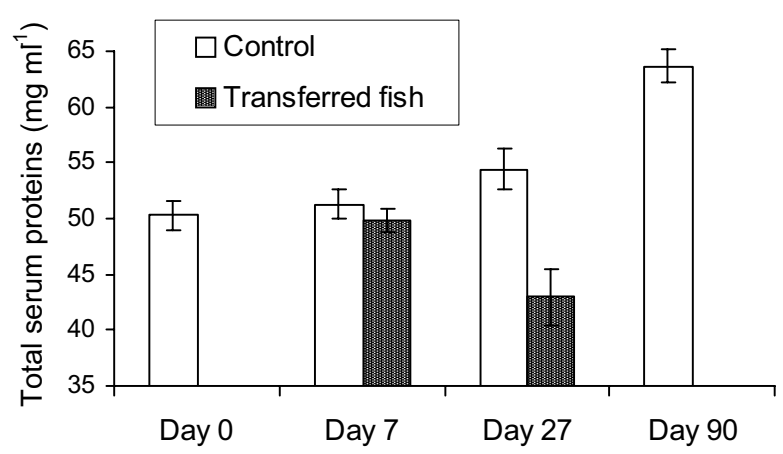

Fig. 3. Total serum protein (TSP, $\mathrm{mg} \mathrm{ml}^{-1} \pm \mathrm{SE}$ ) level decreases in transferred fish and increases in non-transferred fish (control). The two samples from day 27 and successive samples are significantly different $(n=30 ; p<0.05)$, except between day 0 and day 7 .

day 20, and then increased over 2 weeks to reach and exceed calculated TSP $(0.2 \%$ by day). After compensative overproduction (6th and 7th weeks), it fluctuated away from calculated TSP, before returning to these values in the 9th week. The general form of the graph is of interest as it was obtained by compilation PPA results. PPA is used to balance difference in size and sibs of fish. Although it does not allow confidence intervals to be obtained, the number of results here (1300) mitigates this lack.

\section{TSP alteration due to multiple transfers}

Multiple transfers to other tanks induced a decrease in TSP (Fig. 5) with cumulative but lesser effects for the second transfer: $2.93 \mathrm{mg} \mathrm{ml}^{-1}$ for the first and $1.33 \mathrm{mg} \mathrm{ml}^{-1}$ for the second. In parallel, TSP in non-transferred fish increased, with a ratio close to the theoretic progression. A rapid increase appeared after the second transfer, which then slowed around week 7 but only joined and overtook the calculated level at week 14 . The large decreases after day $0(\mathrm{PPA}=-7 \%)$ and day $112(\mathrm{PPA}=$ $-17 \%)$, the smaller decrease after day $15(\mathrm{PPA}=-3 \%)$ and the rapid increase after day $28(+17 \%)$ should be noted. After two consecutive transfers, the fish needed 11 weeks to return to normal TSP level instead of 4 weeks after a single 


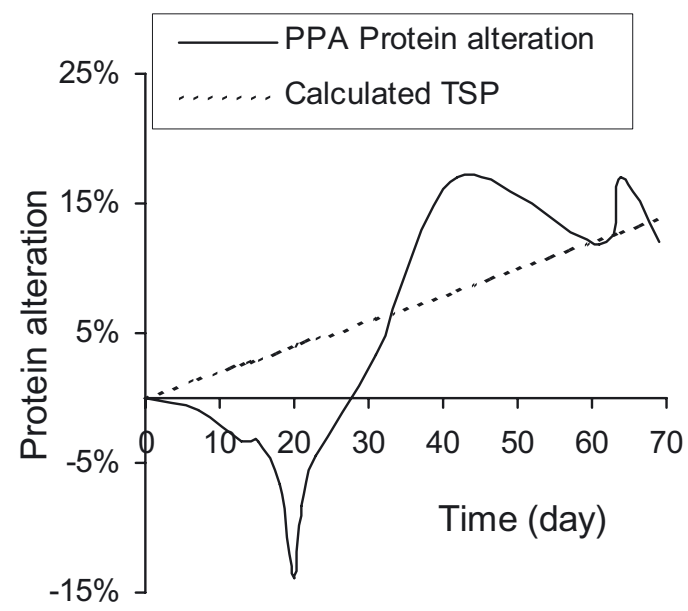

Fig. 4. TSP alteration in 1300 samples (expressed in protein percentage alteration, PPA) after a single transfer, compared with calculated TSP increase $\left(0.2 \%\right.$ day $\left.^{-1}\right)$. Mean PPA is used but it does not allow a confidence interval to be given.

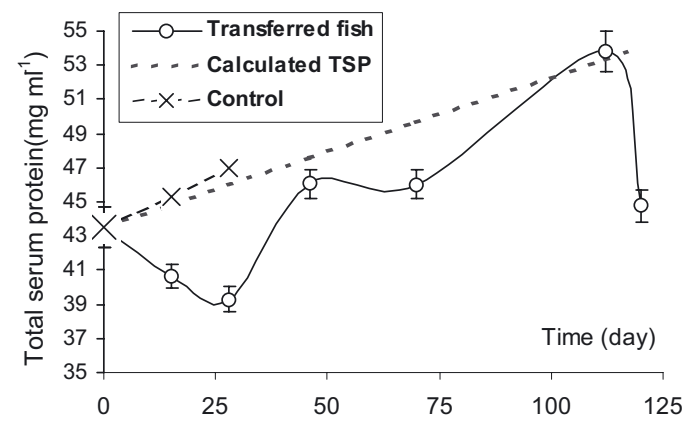

Fig. 5. Cumulative effect on TSP after multiple transfers. One part of the fish group (control) was not transferred during 28 days and the second part was transferred twice: at days 0 and 15. Fish were then left until day 112, when the third transfer was made. The straight line is calculated TSP $\left(0.2 \%\right.$ day $\left.^{-1}\right)$. All consecutive samples were different $(n=30 ; p<0.05)$ except between day 46 and day 70 .

transfer (Fig. 4). One week after the third transfer, TSP had lost $9.07 \mathrm{mg} \mathrm{ml}^{-1}(-17 \%)$.

\subsection{TSP alteration by nodavirus injection}

Electronic tagging of fish enabled individual comparison by using PPA, which balances natural variation in the group and optimizes individual differences obtained with tagged fish.

The results examined here concern fish sampled a second time because $40 \%$ of virus-injected fish died before the second sampling (Fig. 6). The PPA means of virusinjected groups were different (multiple comparison procedures: Dunn's method, $p<0.05$ ) from the control, except the asymptomatic group. Individual PPA of dying fish increased drastically during the first week and then dropped in the second week before the fish died. The whirling group concerned fish that were still alive at day 11 . No more fish presented whirling symptoms later on. This group contained both fish with positive and fish with negative PPA; as was also the case with the live asymptomatic fish. PPA in the control fish decreased

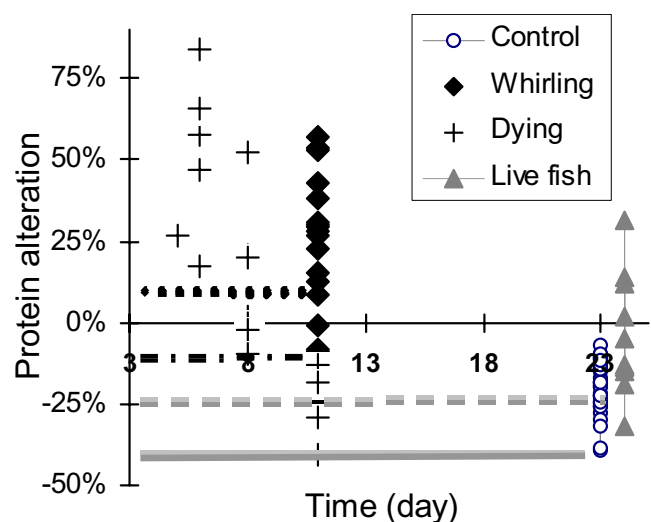

Fig. 6. Protein percentage alteration (PPA\%) according to health status. Individual variation in TSP (expressed in PPA\%) of each fish after live nodavirus injection ( $n=35$ in triplicate). Fish were divided into three groups: Dying fish (+; mean ...), whirling fish ( mean -.-.) and live asymptomatic fish ( $\mathbf{\Lambda}$; mean - - ). Control fish (o; mean -) were injected with sterile seawater SSN1 cells $(n=35)$. The PPA means (horizontal line) of virus-injected groups are different $(p<0.05)$ from the control except for the asymptomatic fish group.

individually and uniformly as a consequence of transfer, as described above, but with lower PPA on day 24 (PPA mean: $-20 \%$ instead of $-14 \%$ for transfer at this time). All means of injected fish were higher than those of control fish (whiling $8 \% \pm 5 \%$, dying $30 \% \pm 8 \%$, asymptomatic $-3 \% \pm 5 \%$ ) and all different $(p<0.05)$ from the control except the asymptomatic $(p>0.05)$. The large SE shows the dispersion of the results. The chronology of mortality is similar to that found in previous work.

\section{Discussion}

Fish showed different TSP responses in relation to their living conditions: differences in TSP occurred in response to hyperoxia and hypercapnia, although these were too erratic to be analysed, low decrease in response to stocking density, and sharp and significant alteration in response to transfer to another tank or to nodavirus injection. Actually, the question is whether TSP can be used to discriminate welfare alteration and possibly stressful conditions or disease in reared sea bass.

Even though other parameters (behaviour, feed, etc.) changed with increased concentrations of $\mathrm{O}_{2}$ or /and $\mathrm{CO}_{2}$ (Taranger 2008), TSP alterations were not significant and neither was its trend. Individual variations made the TSP data unusable, however. This situation is similar to the effect of sublethal exposure to ammonia (Ingram and Alexander 1977; Coeurdacier and Dutto 1999) with potential stress and/or a poisoning effect. Moreover, oxygen and $\mathrm{CO}_{2}$, like ammonia, are normal components of the environment of fish and become toxic only when the dose is increased.

The relation between TSP and stocking density is not well documented. It was found to decrease in "potential crowding" (Sutton et al. 2000); the conditions in this other experiment were different from those in our own, however (modification of the flow rate and water parameters). For the present experiment on density, several hypothesis can be put forward: (i) TSP decrease starts but is compensated by the end of the 
experiment, as previously observed after TSP decrease due to stress (Coeurdacier and Dutto 1999; El-Gohary et al. 2005); (ii) Stocking density has no influence on TSP, but modifies swimming behaviour, affects feed intake, growth and blood $\mathrm{pCO}_{2}$ and $\mathrm{HCO}_{3}$ (Sammouth et al. 2008; Roque d'Orbcastel et al. 2010), as already reported for several blood components in sea bass (Vazzana et al. 2002). In similar experimental conditions to the present ones, an effect on the level of gene expression was found (Gornati et al. 2004). Furthermore, our investigations by $2 \mathrm{D}$ gel and proteomic analysis on tandem mass spectrometry (MS-MS) showed a significant difference in panels of serum protein, with apparition of proteins involved in inflammation (Coeurdacier 2010). In the case of stocking density, TSP is at the limit of its discriminating power.

Transfer stress altered many blood components but not TSP within the first $5 \mathrm{~h}$ in dab (Hutchinson and Manning 1996) and within $96 \mathrm{~h}$ in Matrinxã (Brycon amazonicus) (Urbinati and Falanghe Carneiro 2006). In trout, however, TSP were still lower one week after 2 hours of transportation (Jeney et al. 1997). In our experiments, transfer from tank to tank altered TSP and induced a decrease in transferred fish compared with the normal increase in the non-transferred fish (Figs. 3-5). Diet has already been shown to decrease TSP (Friedrich and Stepanowska 2001) and, as fish were fasted $24 \mathrm{~h}$ before transfer, may have had an influence. In our experimental conditions, TSP decreases in transferred fish but not in non-transferred fish, which are provided with the same diet. After transfer to another tank, fish have different behaviour patterns; nontransferred fish resume feeding rapidly but transferred fish take longer to recover normal feeding. The transferred fish recovered normal TSP at the same time as they recovered normal weight: after 4 weeks. The cause of the change could be a longer fasting period or consumption of serum protein by stress effects or a combination of both, TSP does not permit us to discriminate between these hypotheses.

After transfer (Fig. 4), the normal increase in TSP stops and then the level decreases. PPA decreases over 3 weeks and then increases, with overcompensation after four weeks, to reach the same level as calculated PPA after 9 weeks. Similar overcompensation is observed in sea bass subjected to ammonia stress (Coeurdacier and Dutto 1999)

With multiple transfers (Fig. 5), TSP evolution presented a similar pattern to those observed with a single transfer for the decreasing period ( 3 weeks), but with a longer recovery period (11 weeks instead of 4), showing that multiple transfers have a cumulative effect. TSP decreased less after the second transfer than after the first, even though fish reacted rapidly. Moreover, the dramatic decrease after the third transfer is probably a very bad sign. In fact, animals that were transferred twice within 28 days showed a large protein loss (PPA, -15\%) compared to non-transferred fish. They had to react rapidly by overcompensation to survive, and then production slowed down, either because reserve involvement increased and/or break point level passed.

It seems that two different mechanisms are involved: the former is a normal compensation of protein consumption induced by the first transfer, the latter works urgently to keep the fish alive after the second transfer. The latter probably activated all stress mechanisms and, when a fatal outcome is avoided, a feedback control stops protein overproduction and the former mechanism is resumed. In the case of single or multiple transfers, TSP is a good discriminating parameter. Its variation is significant and lasts for a long time.

Control fish $\left(\mathrm{SSN}_{1}\right.$ injected) presented individual and large decreases (PPA: $-20 \%$ ) lower than the minimum level resulting from transfer $(-14 \%)$. $\mathrm{SSN}_{1}$ cells are a neutral antigen (not pathogenic), like a dead vaccine. Dead Vibrio anguillarum induced decreases in TSP in sea bass (Coeurdacier et al. 1997) and dead Salmonella typhi and human group-O erythrocytes induced a decrease in brown trout (Ingram and Alexander 1977). This mechanism amplifies the decrease due to transfer.

Asymptomatic fish can be divided into two groups, the former with negative PPA (close to control), probably insensitive to nodavirus, like sea bass broodstocks, (unpublished results) and the latter with positive PPA due to the beginning of the IgM production for specific immunization.

In dying fish, TSP increased sharply on the first days by over-production of protein involved in non-specific defences and inflammation, then decreased dramatically before death. The whirling fish group probably contained both fish that would die and those which would recover (5-20\%, Coeurdacier 2002) and develop specific immunity. Both in cases of transfer and infection, TSP is a good discriminating parameter.

Many explanations have been suggested to explain TSP decrease. These are well summarized by Steinhagen et al. (1997), who mentions changes in blood volume and plasma hydration, alterations in permeability of environmental barriers, tissue destruction, malabsorption, and tissue injury by parasites or other pathogens. These hypotheses can explain, by their single or combined action, the results obtained with nodavirus injection, where the stress was strengthened by infection. For the other cases, the protein decrease may be due to their degradation and also to the possible utilization of these compounds for metabolic purposes (Reddy and Bashamohideen 1995). This possibility is strengthened by the increase of low weight molecules but not degraded fractions observed in a proteinogram of control brown trout injected with phosphate buffered saline (PBS) (Ingram and Alexander 1977) and in a proteinogram of sea bass stressed by ammonia (Coeurdacier and Dutto 1999). Modifications of the serum protein panel are consistent with a 2D electrophoresis analysis on stocking density samples (Coeurdacier 2010) and can be explained by an alternative or complementary mechanism: the compensative overproduction started by production of inactive low weight molecules kept as a reserve until needed and later used to build protein (Coeurdacier and Dutto 1999). TSP does not permit this kind of mechanism to be investigated. A new approach using analysis of cellular and molecular immune parameters in a fish exposed to sublethal dose of virus does show promise (Scapigliati et al. 2010)

\section{Conclusion}

All modifications of rearing conditions experimented during this program are less stressful for the fish than a single transfer, although transfer is common farm practice. Our results are a confirmation of the well-known fish farming opinion that handling fish has a bad effect. 
Ways of using TSP on fish farms should be considered. Every month or when necessary, 30 fish in a rearing batch could be sampled to monitor TSP. It should normally increase slowly, as the fish grow. TSP should be used as a routine analysis, because only its variation provides usable information, while its regular increase can attest the adequate welfare of the fish. Sharp increases or decreases in TSP indicate that fish had or have a problem. For sharp TSP increases, infection is a probable cause; for decreases, other stress factors should be investigated. Facilities for the analysis of total serum protein are widespread and easily accessible, on the condition of including a standard, like bovine serum albumin (BSA) protein concentration reference standard $\left(50 \mathrm{mg} \mathrm{ml}^{-1}\right)$. The price is $1-2 €$ in a standard laboratory and $4-5 €$ in a medical laboratory.

TSP is a non-destructive parameter that is robust, easy to measure everywhere and cheap, representing a suitable way of monitoring the overall welfare of fish by its regular increase. However, it can be used only as a "warning" of poor rearing conditions and further investigations would be needed to identify the specific stress or health disorder.

Acknowledgements. We are grateful to Jean-Pierre Baud, IFREMER Nantes, for his help. This work was supported by grants from an E.U. Project: Welfare and health in sustainable aquaculture (WEALTH). Contract No: $\mathrm{N}^{\circ} 501984$.

\section{References}

Adham K.G., Hassan I.F, Taha N., Amin T., 1999, Impact of hazardous exposure to metals in the Nile and Delta lakes on the catfish, Clarias lazera. Environ. Monit. Assess. 54, 107-124.

Carneiro P.C.F., Urbinati E.C, 2002, Transport stress in matrinxã, Brycon cephalus (Teleostei: Characidae), at different densities. Aquac. Int. 10, 221-229.

Coeurdacier J.L., 2002, Les peptides synthétiques en tant que vaccin contre le nodavirus. Rapport final ANVAR A9804041J Annexe 23, Agence Nationale de Valorisation de la Recherche.

Coeurdacier J.L., Dutto G., 1999, Effect of chronic exposure to ammonia on alterations of proteins and immunoglobulins in sea bass (Dicentrarchus labrax) serum. Aquat. Living Resour. 12, 247-253.

Coeurdacier J.L. 2010, Proteomic approach to investigate alternations, within physiological limits, in serum protein of sea bass (Dicentrarchus labrax). French-Japanese Symposium, Sète, France, Proceeding 120-124.

Coeurdacier J.L., Laporte F., Pepin J.F, 2003, Preliminary approach to find synthetic peptides from nodavirus capsid potentially protective against sea bass viral encephalopathy and retinopathy. Fish Shellfish Immunol. 14, 435-447.

Coeurdacier J.L., J.F. Pepin, C. Fauvel, P. Legall, A.F. Bourmaud, B. Romestand, 1997, Alterations in total protein, IgM and specific antibody activity of male and female sea bass (Dicentrarchus labrax L., 1758) sera following injection with killed Vibrio anguillarum. Fish Shellfish Immunol. 7, 151-160.

El-Gohary M.S., Safinaz G., Mohamed K.R.H., El-Banna S., Soliman M.K., 2005, Immunosupressive effects of nitrofonate on Oreochromis nilotus. Egypt. J. Aquat. Res. 31, 448-458.

Friedrich M., Stepanowska K., 2001, Effect of starvation on nutritive value of carp (Cyprinus carpio L.) and selected biochemical components of its blood. Acta Ichthyol. Piscic. 31, 29-36.
Gopal V., Parvathy S., Balasubramanian P.R., 1997, Effect of heavy metals on the blood protein biochemistry of the fish Cyprinus carpio and its use as bio-indicator of pollution stress. Environ. Monit. Assess. 48, 117-124.

Gornati R., Terova G., Vigetti D., Prati M., Saroglia M., Bernardini G., 2004, Effects of population density on seabass (Dicentrarchus labrax L.) gene expression. Aquaculture 230, 229-239.

Hutchinson T.H., Manning M.J., 1996, Seasonal trends in serum lysozyme activity and total protein concentration in dab (Limanda limanda L.) sampled from Lyme Bay, U.K. Fish Shellfish Immunol. 6, 473-482.

Ingram G.A., Alexander J.B., 1977, Serum-protein changes in brown trout (Salmo salar L.) after single injections of soluble and cellular antigens. J. Fish Biol. 11, 283-291.

Jeney G., Galeotti M., Volpatti D., Jeney Z., Anderson D.P., 1997, Prevention of stress in rainbow trout (Oncorhynchus mykiss) fed diets containing different doses of glucan. Aquaculture 154, 1-15.

Magnadottir B., Jonsdottir H., Helgason S., Bjornsson B., Jorgensen T.O., Pilstrom L., 1999, Humoral immune parameters in Atlantic cod (Gadus morhua L.). I. The effects of environmental temperature. Comp. Biochem. Physiol. B 122, 173-180.

Reddy P.M., Bashamohideen M., 1995, Alterations in protein metabolism in selected tissues of fish, Cyprinus carpio, during sublethal concentration of cypermethrin. Environ. Monit. Assess. 36, 183-190.

Riche M., 2007, Analysis of refractometry for determining total plasma protein in hybrid striped bass (Morone chrysops $\times M$. saxatilis) at various salinities. Aquaculture 264, 279-284.

Roque d'Orbcastel E., Lemarié G., Breuil G., Petochi T., Marino G., Triplet S., Dutt, G., Fivelstad S., Coeurdacier J.L., Blancheton J.P., 2010, Effects of rearing density on sea bass (Dicentrarchus labrax) biological performance, blood parameters and disease resistance in a flow through system. Aquat. Living Resour. 23, 109-117.

Sammouth S., d'Orbcastel E.R., Gasset E., Lemarie G., Breuil G., Marino G., Coeurdacier J.L., Fivelstad S., Blancheton J.P., 2008, The effect of density on sea bass (Dicentrarchus labrax) performance in a tank-based recirculating system. Aquac. Eng. 40, $72-78$.

Scapigliati G., Buonocore F., Randelli E., Casani D., Meloni S., Zarletti G,. Tiberi M., Pietretti D., Boschi I., Manchado M., Martin-Antonio B., Jimenez-Cantizano R., Bovo G., Borghesan F., Lorenzen N., Einer-Jensen K., Adams S., Thompson K., Alonso C., Bejar J., Cano I., Borrego J.J., Alvarez M.C., 2010, Cellular and molecular immune responses of the sea bass (Dicentrarchus labrax) experimentally infected with betanodavirus. Fish Shellfish Immunol. 28, 303-311.

Steinhagen D., Oesterreich B., Korting W., 1997, Carp coccidiosis: clinical and hematological observations of carp infected with Goussia carpelli. Dis. Aquat. Org. 30, 137-143.

Sutton R.J., Caldwell C.A., Blazer V.S., 2000, Observations of health indices used to monitor a tailwater trout fishery. N. Am. J. Fish. Manage. 20, 267-275.

Taranger G.L., 2008, Welfare and health in sustainable aquaculture (WEALTH). Coord. Geir Lasse Taranger, Final report. EU Project no. N501984, http://wealth.imr.no/

Urbinati E.C., Carneiro P.C.F., 2006, Sodium chloride added to transport water and physiological responses of matrinxã Brycon amazonicus (Teleost: Characidae). Acta Amaz. 36, 369-572.

Vazzana M., Cammarata M., Cooper E.L., Parrinello N., 2002, Confinement stress in sea bass (Dicentrarchus labrax) depresses peritoneal leukocyte cytotoxicity. Aquaculture 210, 231-243. 